\title{
Introduction
}

Where does indigenous culture fit into the twenty-first-century challenge of creating a sustainable, and equitable, global society on a habitable planet? At first blush, there seems to be little place for indigenous culture in this immense project. In the 2030 Agenda for Sustainable Development, where the United Nations Sustainable Development Goals (SDGs) are meticulously displayed, there is little mention of indigenous people other than an appearance in longish lists of vulnerable populations that should be targeted and consulted during sustainable development planning. The 17 SDGs and 169 associated targets make no mention of indigenous culture. If we look at the SDGs in isolation, we may feel that indigenous peoples feature only as targets of modernist, managerial, technocratic development. The SDGs certainly do not evoke a sense that sustainable development will be guided in any way by indigenous cosmovisions and holistic understandings of nature-human relationships.

Away from the strict delineations of the SDGs, however, we do see many instances where indigenous culture is described as integral to environmental sustainability. In places, indigenous culture has been evoked as a discursive corridor through which we may access another, amodern, and perhaps premodern form of development to challenge extractivist, modernist development teleologies (Blaser et al. 2004). It has also been framed as a political-economic resource with which equity and environmental protection may be produced (Yúdice 2003). The United Nations Education, Science, and Cultural Organization (UNESCO 2019) 
recognizes culturally embedded indigenous knowledge of ecosystems as essential "for developing meaningful action worldwide" in the interest of sustainable development. Similarly, the UN Department of Economic and Social Affairs (UNDESA) website claims that "[i]ndigenous communities play a vital role as custodians of our planet, possessing vital knowledge that will support global efforts to achieve the Sustainable Development Goals." In a National Geographic magazine article, Raygorodetsky (2019) has echoed these refrains, suggesting that modern society must learn the holistic relational viewpoints integral to indigenous culture in order to solve the challenging environmental problems of the Anthropocene.

But what does the indigenous contribution to the economics and politics of sustainable development look like from the ground up? What has been, is, and may be, the contribution of indigenous culture to the reimagining of human progress? This book explores indigenous cultures and movements in Latin America, as well as the history of culture in development thinking, to answer these questions. Far from being an antithesis of development in general, the argument will be presented that indigenous culture has always been present, if greatly marginalized, in the intellectual movements that frame progress, environment, and development. Similarly, it will be argued that although indigenous culture continues to be marginalized in very violent and systematic ways, it inhabits a creative and increasingly important place in the economic, ecological, social, and cultural reimagining of global human and non-human society. To make this case, it will be necessary to wrestle with some famously ambiguous concepts.

It is difficult to imagine a triumvirate of words that could be more ambiguous than culture, sustainability, and development. The first of these words has been noted by Raymond Williams (1977) as being "one of the two or three most complicated words in the English language" (p. 76); the next has been criticized for being an empty notion that changes meaning depending on the user (Redclift 2005); and the third is an embattled concept that continues to have multiple definitions (Cowen 2003). Despite the semantic ambiguity of these terms, however, engagement with them cannot be avoided if we care about making life more livable for the majority of people on the planet.

There are good reasons for believing this. In contrast to the stale economism of the twentieth century, the twenty-first century has seen a rise in awareness that culture, politics, and economy are inseparable. A steadily accumulating mountain of literature contains arguments to this effect from many perspectives. Particular cultures, it has been argued, can act as 
the rich soil in which economies and political systems flourish. Others have been cast as barren dustbowls in which these systems perish (Harrison and Huntington 2002). From a different perspective still, it has been argued that competitive consumer culture in the West may have precipitated the multiple, and continuing, series of economic bubbles and corresponding crashes that have tormented the globe in recent years and that this same culture may have pushed global ecosystems beyond their capacity to sustain us (Heinberg 2011; Schor 2004). More substantively still, it has been argued that it is culture that shapes our values-determining what counts as progress and development in the first place (Sen 2004).

All of these cultural considerations complicate both the everyday practice of development and the theoretical underpinnings of this practice. Before conceiving of development projects, for example, practitioners must decide whose cultural idea of development ought to be the goalthat of the funding agency, or its home country; that of the practitioner, or that of the target population. Similarly, questions must be addressed regarding the value of culture. Should traditional culture be shed as an impediment to development? Should traditional societies be protected from the cultural change that development seems to carry with it? Is there such a thing as traditional culture at all? Can traditional or indigenous culture be retained while still achieving something that might be called development? Finally, can development be reimagined from the nonEurocentric starting point of indigenous culture?

Understanding the interaction of culture and development is not only important for development practitioners working in the Global South, however. We live in a time of global ecological, political, and economic crisis. Many have wondered if it is not modern culture itself that is at the root of such upheaval (Hamilton et al. 2015). As we face ecological and political barriers to the expansion of the current global economic system, it is culture that will allow us to imagine the social and economic innovations that will help us transcend the global turmoil of the early twentieth century. This may involve a re-evaluation of our personal goals, desires, values, and aspirations. It may also include a reimagination of what we call progress, development, economic growth, and the good life, on a global level. Such moves would require a reformulation of the social, political, and economic policies that we use to achieve these lofty goals. It may be the case that traditional or indigenous culture has something to teach modern culture in this regard. 
Exploring the folds, fissures, and fuzzy edges of culture is not an easy task, however. Culture, of course, is the very thing we use to order and understand our social world. Policymakers, practitioners, consumers, voters, and intellectuals alike can only think through their own culture. It frames our thoughts-determining what is imaginable and comprehensible to us. Ideas such as progress, development, and gross domestic product are entrenched in the culture of modernity and are ubiquitous in our globalized world. There is no escape, or outside vantage-point from which to gaze on these complex perceptions. One cannot escape their cultural logic by going to the remote beaches of the Corn Islands, the mysterious oxbows of the Amazon basin, or the lush highlands of Guatemala. We will not meet an indigenous tribe on an excursion to the interior of Sumatra that will impart on us the lost and pristine wisdom of an ancient culturehelping us to see clearly an alternative to corrosive Western practices, or the secret of culturally appropriate development. How, then, do we begin to rethink some of our most dearly held beliefs and associated social and economic policies?

In the absence of a clear "outside-looking-in" position, there is no easy way to rethink our world. Given this reality, what is required is a careful and open-minded look at the history of policy related to the idea of development. We must understand the ways in which we have thought of the economy and its relation to culture in the past before we can open new territory for the future. In other words, we must understand culture of development the way it is before pushing it in new directions. This is the only way we can avoid falling into past habits of thought.

That is the first step in imagining new directions in social and economic policy. The second step is to try and understand instances where modern culture is already being pushed in new directions. All culture is varied, constantly changing, but also connected. This is certainly the case in our often contested and diverse global culture. From this, we can realize that although there is no outside to the culture of global modernity, it constantly mutates and it does have edges. Amongst these edge-areas we may include things such as tribal wisdom from the Amazon, the colonially suppressed knowledge of Maya cosmovision, or anarchist strains of North American and European intellectualism. These ephemeral and constantly changing edges of modernity can be explored in order to imagine alternative futures. By doing such exploration, new ideas can be folded into mainstream society from its innovative edges, and more effective development projects can be devised. 


\section{Transmodernity and Neoliberal Multiculturalism}

The purpose of this book is to begin the work of reimagining development by taking two important first steps. First, there will be a detailed look at the way in which culture relates to the long history of thought on development and progress. Second will be an investigation of three examples of indigenous-driven sustainable development projects from Latin America. These edge-ideas occur on multiple scales within three countriesGuatemala, Honduras, and Ecuador-and have international linkages between each other, as well as with broader indigenous rights and environmental movements.

Through the relation of Latin American indigenous movements and the history of Western thought on culture and development, the argument will be made that indigenous sustainable development is not an amodern or postmodern idea. It is better framed as transmodern. When discussing indigenous ideas of development, it is easy to fall into two conceptual traps. The theoretical construct of transmodernity helps us to avoid these errors. The first, the essentialist trap, results from the reification of indigenous cultures as eternal, pre-historical, and unchanging. The second, the strategic essentialist trap, positions indigenous movements, politics, and identity solely as calculated tactical reactions to current legal institutions and discourses (Paradies 2006).

The theory of transmodernity is part of a research paradigm that is emerging largely from Latin America, but is applicable throughout the globe (Dussel 2012; Herrera Guillén 2016; Arias 2017; Escobar 2007). The theory begins with the assertion that non-modern cultures were not erased by colonialism or neocolonialism, but remained hidden, subverted, and marginalized. As Dussel (2012) argues, they were pushed to the edges, or the borders of modernity, where they continued to interact creatively with it. In fact, these cultures contributed to the creation of modernity through their labour, cultural traditions, and struggles for rights, freedoms, and nations. Modernity, this implies, was not fully established before colonization, but evolved with substantial contributions from the premodern cultures at its edges. As such, transmodern cultures do not reject all elements of modernity (Escobar 2007). These points differentiate transmodern movements from anti-modern and postmodern ones according to Dussel (2012). As he explains, transmodernity "assumes the positive moments of Modernity" as cultures that have been pushed to its edges to deconstruct their own traditions, while they challenge European 
cultural hegemony using "critical elements" adopted from their own traditions and also "others adopted from Modernity itself" (18-21).

Dussel's argument suggests that transmodern cultures cannot be accurately described as postmodern, since the bulk of their cultural elements have never been entirely modern, and draw substantively on the premodern. Importantly, the movements associated with transmodernity seek decolonization through self-valorization as they combine their own premodern cultural elements with the most progressive tools of modernity, and discursive exchange with other transmodern elements across the globe. In this way, subsistence practices, nature-relatedness, and diverse cosmovisions are combined discursively with appeals to rights, democracy, sovereignty, and equality, while local, national, and transnational identities are reformed and reworked (Escobar 2007).

Another important concept related to current articulations of culturally sustainable development is neoliberal multiculturalism. This concept, which has been most notably explored by Charles Hale (2006), forefronts a rarely acknowledged tension within the current manifestation of neoliberalism. In our current post-Washington Consensus global policy climate, collective government political power has been diminished, while the economic power of markets has become dominant. As property rights have been sanctified and individualistic ideology has been reinforced, nongovernmental organizations, community groups, and indigenous movements have asserted rights through claims to collective cultural rights. As Hale (2006) put it:

Neoliberalism encompasses economic doctrine but also promotes a reorganization of "political society" along the lines of decentralization, trimming down of the state, affirming basic human rights, and calling for minimally functional democracies. ... [N]eoliberalism brings forth a new direction in social policy, emphasizing the development of civil society and social capital, and an approach to cultural rights that at first glance appears highly counterintuitive. (p. 12)

As we will explore in this book, the neoliberal period has also seen the rise of movements for cultural protection and indigenous rights. In many Latin American countries, indigenous culture has moved in status away from that of a remnant of pre-Columbian backwardness and towards a national resource to be embraced. Accordingly, states such as Ecuador, Honduras, and Guatemala have come to support the resuscitation of 
indigenous dress, language, tradition, and culture. This process is helped along by an international development funding system that has come to recognize indigenous culture as a form of social capital. Along with this, national commitments to indigenous rights instruments such as the International Labour Organization Convention 169 Convention on Indigenous and Tribal Peoples have also helped.

The elevation of indigenous rights and culture goes only so far, however. Where indigenous rights and community organizations threaten transnational capital investments, neoliberal multiculturalism reaches its limit. Repression of indigenous groups and communities becomes common in such instances. Neoliberal multiculturalism has no difficulty respecting the rights of individuals to not be discriminated against due to their ethnicity or any other reason. It protects private capital with legal instruments, and often repressive power, however, when ethnic minorities make claims to material resources such as land, wage shares, or personal wealth. This is the tension faced by transmodern Latin American indigenous groups as they seek to rewrite the concept of development from their perspective.

\section{Outline of THE BoOK}

Tensions around transmodernity and neoliberal multiculturalism will be apparent in the explorations of this book. We will see that indigenous ideas of development are at once old and new, modern and amodern-properly transmodern. We will explore the way in which indigenous cultural understandings can inform, and are informed by, new global ideas of development that are respectful of cultural differences and ecological limits. We will also see how transmodern indigenous development draws from and continues to contribute to centuries-old political-economic thinking about the meaning of progress, development, and culture. It is hoped that understanding indigenous redefinitions of these concepts will aid development thinkers, policymakers, practitioners as well as citizens in reimagining social, political, and economic policy in a time of multiple global crises.

As argued earlier, culture is a central term in this discussion. Understanding the place of this term vis-à-vis ideas of development and progress is key to developing the understanding we need in order to take the first step in reimagining development thinking. This work will begin in Chaps. 2 and 3 by tracing the strands of culture in ideas of development and progress that began in the late eighteenth century. Allusions (or lack 
thereof) to the concept of culture and to culture-like ideas will be located in the works of Adam Smith, Karl Marx, Alfred Marshall, and others. These works are keystones to the large edifice of modern thought on progress and development. To examine them is to examine the intellectual history of our culture and the cultural history of our intellect as it relates to progress, development, politics, and economy.

This analysis will continue in Chaps. 4 and 5 , but the focus will be shifted to post-WWII development thought. This is a time in which discourses around the topics of economy, politics, development, and progress were extraordinarily diverse and contested. Different policy frameworks were imagined, and the politics around these had immense human and environmental consequences. Works produced by W.W. Rostow, Andre Gunter Frank, Amartya Sen, Arturo Escobar, and many others will be mapped according to their treatment of culture. They will be also historically contextualized as key features of discourses that spin around the central concept of development.

In Chap. 6, attention will be turned to Guatemala, El Centro Pluricultural para la Democracia, and the Maya idea of culturally sustainable development (CSD). An attempt will be made to understand the historical forces out of which El Centro and CSD have emerged. The hope is that such historical understanding will help in the proper conceptualization of the work and the ideas of the organization. This is a story of marginalization, global economics, and civil war, mixed with allusions to Maya cosmovision and aspirations to a better future - that is, to progress and development. It is a story of continuing struggle to develop and implement a new kind of development amidst racial and economic marginalization, genocide, and war.

The historical and spatial situation of El Centro from Chap. 6 will serve as the contextual basis for a description of the organization, its ideas, and its work that will be expounded in Chap. 7. This account is based on textual interpretation of the organization's publications, participant observation, qualitative interviews, and focus groups undertaken with members of El Centro between 2006 and 2015.

It is in this chapter where the idea of culturally sustainable development will be described and explored in full. This chapter represents and attempts to answer the question "what is CSD and how does it work?" Central to the topic is the concept of cosmovision-the component of culture that orders the way in which one understands the functioning of the cosmos, the relation of human to human, and human to nature. Members of $E l$ 
Centro argue that to make development culturally sustainable in Guatemala's Western Highlands requires that the entire process be guided by Maya cosmovision. To understand CSD, one must have at least a clumsy understanding of Maya cosmovision, among other important elements. All of these are explored in Chap. 7.

Chapter 8 results from ongoing field research I have undertaken since 2011 with Afro-indigenous Garifuna communities in Honduras. To understand the Honduran Afro-indigenous movement, and locally sourced sustainable development ideas that are associated, it is necessary to grasp important elements of Garifuna history and current political economy. The chapter shows how hybrid Garifuna culture formed via colonialism and anti-colonialism, how the repressive Honduran state and predatory international capital constrain current development possibilities, and how the Garifuna use international solidarities to form a resistance, and development alternative, around the idea of indigenous food sovereignty.

Chapter 9 looks at a national-level project in Ecuador, where I have been involved in research since 2007. Indigenous sustainable development in that context revolves around the idea of Sumak Kawsay (living well), which has been incorporated, somewhat problematically, into the national constitution. This particular cosmovision will be discussed, as will events around the formation of the national constitution. Following this, I will describe the life and death of an innovative national programme to acquire international funding to "keep the oil in the ground" in biologically sensitive indigenous territories. This description of the Ecuadorian case provides a nuanced understanding of the key multiscale issues facing indigenous sustainable development.

In Chap. 10, these indigenous alternative ideas of development will be compared and contrasted with the discourse of international development literature that was set out in Chaps. 2, 3, 4, and 5 . This will be done by attempting to understand where indigenous sustainable development can easily be incorporated into the more well-known theories, when it cannot, and when such incorporation threatens to mutate powerful theories of development into something very new. This last consideration becomes particularly interesting when the relationship between development economics and indigenous development is considered. The work of this chapter helps us to begin to think outside of our culturally prescribed intellectual boxes in tackling the most important issues of our time. 
All of the ideas of the book are synthesized and reflected on in Chap. 11, the final chapter. More importantly, this chapter specifically engages the idea of sustainable development. Mainstream ideas, encapsulated in the SDGs, are compared with indigenous ideas of sustainable development. Important tensions between the two are located, and ways in which indigenous thought can guide mainstream development policy are suggested.

The book in total seeks less to find easy answers than to begin a long intellectual journey. This journey may well end in the transformation of society, but this book only begins to address that great challenge. Both the journey and the book start with an attempt to understand how the concept of culture has been intertwined with our ideas about development, progress, economy, and policy. That work needs to be followed by the examination of multiple indigenous transmodern edge-ideas in our globalized neoliberal society.

\section{InTERPRETING Indigenous Culture}

As we have discussed already, the second part of this book is an interpretation of the most prominent Latin American examples of such ideas. An attempt is made to understand the complex historical terrain that has produced these indigenous movements, their members, and their ideas. The ideas themselves are interpreted and elucidated, and finally - in an attempt to make them more intelligible to Western-trained academics and policymakers - they are explored in relation to the more globally powerful discourses on development that were delineated in the beginning of the journey. It is hoped that others may take this framework to study other edge-ideas-perhaps eventually helping us to think our way out of our current global conundrum of economic instability, inequality, and environmental catastrophe, and perhaps helping us to devise better development projects.

For me personally, this intellectual journey was accompanied necessarily by a continuing ethical introspection. At its core, this project is an attempt to create a representation of members of historically marginalized groups. Such work must be done with a strong sense of ethical responsibility to both the politics of the represented "Other" and to the validity of the research. Nowhere has this type of self-reflection proven more important than in discussions of indigeneity in Guatemala. Even the most careful of sympathetic ethnographies, for example, have been criticized by their 
subjects as undermining their political objectives (Warren 1998). Accounts of Guatemalan history, which arose from the mouths of indigenous Maya leaders through their Western anthropological intermediaries, have been criticized as misrepresentations (Menchú and Burgos-Debray 1984; Stoll 2008). These criticizers have then been critiqued themselves for undermining the political and social justice objectives of marginalized peoples all in the name of the Western ideal of objective truth (Arias 2017).

All of this implies that a representation such as that which appears in this study is necessarily undertaken through dense tangles of political and ethical underbrush. Throughout the process, the need to create a critical and accurate description will be acknowledged. But this will constantly be balanced with a necessity to avoid undermining Latin American indigenous political movements, of which even the most integrated investigator can only hope to attain a partial understanding.

To the extent to which such a balance is achieved, it will not be accomplished by avoiding criticism of indigenous movements and their ideas. The "hard" questions must be asked of movements for indigenous development, but they are asked while members are both literally and figuratively "in the room." Such open criticism was built into the research process for this book. Tricky questions were posed to indigenous leaders. In this context, for example, members were asked questions about the possibility that the largely university-educated members of El Centro are disconnected from the often illiterate members of the communities with which they work. In other words, are the people who work at El Centro really members of the communities with which they work, or part of an educated indigenous elite class that has separate interests and understandings from the most impoverished Maya citizens?

Another difficult question involved claims of culturally rooted proclivities to environmental stewardship that are the centrepiece of many indigenous organizations' programmes. Are these little more than politically motivated fictions? Similarly, is gender equality really a central feature of Maya, Garifuna, and Kechwa culture as advocates seem to assume, or would a revitalization of indigenous belief systems simply work to reinforce culturally rooted inequalities? Such questions were asked openly, and the responses generated understandings that were integrated into my interpretation of indigenous movements and their ideas. This interpretation was then presented to community members themselves, in a focusgroup setting, for their consideration and discussion. Often, follow-up contact was made in order to validate the accuracy of my interpretations. 


\section{Conclusion}

Holding these interpretive and representational issues aside, this work does have a central focus. It seeks to describe indigenous sustainable development and compare it with other ideas of development to the end of developing new policy and new perceptions of the possibilities of human society. In the end, it is found that the inclusion of edge-ideas and indigenous cosmologies in conversations about development necessitates a major rethink of traditional Western frames of analysis. This is a good thing since now, more than ever, we are in need of modifying the central ideas of our global civilization and of devising more effective development programmes.

Constantly circling this central question, however, are issues related to representation, essentialism, and politics. Just as important as the conclusions attained regarding the central question, were the necessary conclusions reached on these encircling issues. What were these conclusions? First, ideas of development are political. There is no avoiding the politics in the name of some imaginary "truth." Second, representations that foreigners create of their often romanticized "Others" will always be imperfect. The trick is to be aware of this throughout the project and to integrate participatory safeguards into the research or development project.

Finally, questions regarding the historical factuality of indigenous essentialist cultural claims will always miss the point. Cultures move, and they are always projects of construction and reconstruction. Claims to cultural essences that are made by indigenous organizations are part of this process. They are part of a global-scale imagining of indigeneity that is not just set on the work of defining indigenous culture, but perhaps of redefining all cultures as they interact with one another and engage with issues of poverty, development, democracy, and environment. In the case of the indigenous ideas presented in this book, the best, most democratic and environmentally sound aspects of a diverse cultural heritage are being centralized in this process. This is part of a cultural project to create a sustainable and democratic future, not to glorify an imaginary past.

Before joining indigenous movements in the re-evaluation of the political and economic structures of our world and the reimagination of development practice, however, we must understand where these ideas came from. That requires us to explore the murky ambiguities, stark disjunctures, and not-so-subtle politics of the intellectual and cultural history of the idea of development. This will be the work of the text two chapters. 


\section{REFERENCES}

Arias, A. (2017). Indigenous Knowledges and Sites of Indigenous Memory. TRANSMODER NITY: Journal of Peripheral Cultural Production of the LusoHispanic World, 7(1).

Blaser, M., Feit, H. A., \& McRae, G. (Eds.). (2004). In the way of development: Indigenous peoples, life projects, and globalization. IDRC.

Cowen, M. P. (2003). Doctrines of Development. Routledge.

Dussel, E. D. (2012). Transmodernity and Interculturality: An Interpretation from the Perspective of Philosophy of Liberation. Transmodernity, 1(3), 28-59.

Escobar, A. (2007). Worlds and Knowledges Otherwise: The Latin American Modernity/Coloniality Research Program. Culturalstudies, 21(2-3), 179-210.

Hale, C. (2006). Neoliberal Multiculturalism: The Remaking of Cultural Rights and Racial Dominance in Central America. Political and Legal Anthropology Review, 28(1), 10-28.

Hamilton, C., Gemenne, F., \& Bonneuil, C. (Eds.). (2015). The Anthropocene and the Global Environmental Crisis: Rethinking Modernity in a New Epoch. Routledge.

Harrison, L. E., \& Huntington, S. (2002). Culture Matters: How Values Shape Human Progress. Basic Books.

Heinberg, R. (2011). The End of Growth: Adapting to Our New Economic Reality. New Society Publishers.

Herrera Guillén, R. (2016). The Lost Modernity: 1436-1439 (Alfonso de Cartagena and Leonardo Bruni). TRANSMODER NITY: Journal of Peripheral Cultural Production of the Luso-Hispanic World, 6(2).

Menchú, R., \& Burgos-Debray, E. (1984). I, Rigoberta Menchú: An Indian Woman in Guatemala (A. Wright, Trans.). London: Verso.

Paradies, Y. (2006). Beyond Black and White: Essentialism, Hybridity and Indigeneity. Journal of Sociology, 42(4), 355-367.

Raygorodetsky, G. (2019). Indigenous Peoples Defend Earth's Biodiversity - But They're in Danger. National Geographic, June, 2019.

Redclift, M. (2005). Sustainable Development (1987-2005): An Oxymoron Comes of Age. Sustainable Development, 13(4), 212-227.

Schor, J. (2004). Born to Buy: The Commercialized Child and the New Consumer Culture. New York: Scribner.

Sen, A. (2004). How Does Culture Matter? In Culture and Public Action (p. 38). Stanford, CA: Stanford University Press.

Stoll, D. (2008). Rigoberta Menchu and the Story of All Poor Guatemalans. Boulder: Westview Press.

UNESCO. (2019). Indigenous Peoples. Retrieved June 21, 2019, from https:// en.unesco.org/indigenous-peoples. 
Warren, K. (1998). Indigenous Movements and Their Critics: Pan-Maya Activism in Guatemala. New Jersey: Princeton University Press.

Williams, R. (1977). Marxism and Literature. Oxford and New York: Oxford University Press.

Yúdice, G. (2003). The Expediency of Culture: Uses of Culture in the Global Era. Durham: Duke.

Open Access This chapter is licensed under the terms of the Creative Commons Attribution 4.0 International License (http://creativecommons.org/licenses/ by $/ 4.0 /$ ), which permits use, sharing, adaptation, distribution and reproduction in any medium or format, as long as you give appropriate credit to the original author(s) and the source, provide a link to the Creative Commons licence and indicate if changes were made.

The images or other third party material in this chapter are included in the chapter's Creative Commons licence, unless indicated otherwise in a credit line to the material. If material is not included in the chapter's Creative Commons licence and your intended use is not permitted by statutory regulation or exceeds the permitted use, you will need to obtain permission directly from the copyright holder.

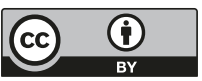

